Author's accepted copy of

\title{
Russia and the politics of extraverted urbanism in the 2014 Winter Olympics and the 2018 FIFA World Cup
}

\author{
Oleg Golubchikov (golubchikovo@cardiff.ac.uk) \\ Sven Daniel Wolfe (SvenDaniel.Wolfe@unil.ch) \\ Accepted for publication in
}

Sport, Statehood and Transition in Europe: Comparative perspectives from post-Soviet and post-socialist societies

Edited by Ekain Rojo-Labaien, Álvaro Rodríguez Díaz, and Joel Rookwood 


\title{
Russia and the politics of extraverted urbanism in the 2014 Winter Olympics and the 2018 FIFA World Cup
}

\author{
Oleg Golubchikov and Sven Daniel Wolfe
}

\author{
Introduction: sport, statehood and space
}

'I'm sorry, every room is booked!' exclaimed the woman behind the desk the hotel (June 2018, Sochi). Four years after the 2014 Winter Olympics in Sochi, now at high season, it seemed to be the same situation at every hotel in Krasnaya Polyana, the new resort built in the Caucasus Mountains for the Olympics. The city bustled with tourists from all around Russia, walking along the local river embankment, exploring the shopping opportunities, dining in the cafes and restaurants, and riding gondolas up to the mountain peaks. Far from the underused wasteland predicted by many commentators, Krasnaya Polyana, the mountainous resort 60km from Sochi, has retained its popularity after the Olympics. Overall, the region of Greater Sochi - historically a desirable vacation destination - has only recently increased its capacity to attract tourism. This has helped drive the regional economy, resulting in enhanced regional incomes and reduced unemployment locally, with many quality of life indicators having improved. Despite some publicised controversies (notably its doping scandal), it appeared as though the Winter Olympics had succeeded in developing tourist infrastructure and boosting the regional economy in this part of Russia (Nureev et al., 2014).

Following a similar pattern, eleven cities centred in the European part of Russia underwent large-scale infrastructural developments in preparation to host the 2018 FIFA Men's Football World Cup (World Cup). Particularly notable is the attention paid to investing in Russia's more peripheral cities, beyond its popular locations and destinations. Unlike Moscow, St Petersburg and now Sochi (all three of which also hosted World Cup matches), many of the other host cities required considerable construction to fulfil FIFA requirements. Prior to the World Cup developments, many of the selected locations experienced considerable problems with basic municipal services like power and water, poor quality roads, aging airports and train stations in need of maintenance. During the World Cup however, 7.7 million visitors and unprecedented numbers of domestic tourists were greeted by new or upgraded transit hubs facilitating travel between and within destinations.

However, although these projects signify a new level of federal involvement in Russia's regional development and demonstrate rapid urban regeneration, they have also in many cases perpetuated or exacerbated the underlying problems of social and spatial inequalities. Mega event preparations created opportunistic conditions for corruption and rapid enrichment on state contracts, allowed for the rushed completion of projects to take priority over the quality of their design, and created new challenges such as maintaining and sustaining newly built and sometimes oversized sporting infrastructure.

This chapter examines some of these complexities, and critiques the nar- rowness of existing literature on these events. Several special journal issues have recently been dedicated to the analysis of Sochi and other post-Soviet mega-events, for example: Sport in Society (Petersson et al., 2015), European Urban and Regional Studies (Müller \& Pickles, 2015); East European Politics (Müller, 2014) and Problems of PostCommunism (Arnold \& Foxall, 2014). There is a tendency in such work to attribute the Russian leadership's logic for investing significant resources in these events as a desire to demonstrate the country's reemergence as a super power externally, and to legitimise Vladimir Putin's personal power domestically. Of course, by hosting popular events, national and local elites in any country seek to boost national pride domestically and 'advertise' themselves externally. There is a trend among emerging economies of hosting sports mega events in order to build an improved status on the world stage (Black \& Westhuizen, 2004; Cornelissen, 2010) and Russia joins China, Brazil and South Africa as recent hosts of the world's most prestigious mega events. Such tournaments have long been recognised as vehicles for nation-building and inspiring national pride and unity (Anderson, 2006; Horne \& Manzenreiter, 2006). This sense of national pride - and as a geopolitical extension the host nations' desire to boost their soft power - are features of most high-status global sports events (Grix \& Brannagan, 2016; Preuss \& Alfs, 2011). However, in AngloAmerican scholarship, most work still tends to perpetuate a reductionist narrative regarding contemporary 
Russia, stemming from a largely one-dimensional perspective that elides the existence of multidimensional domestic political realities in Russia. After all, Russia is not (only) Putin, yet viewing developments through this limited lens risks missing the wider significance of hosting these events. Furthermore, following the Western media's representation (Wolfe, 2015), another prevailing notion here is that the Sochi Winter Olympics and other sports mega events in Russia have produced and engaged in destructive practices which are remote from their declared intentions. Those perspectives inhibit fuller considerations of actual existing legacies, and particularly the diversity of social, spatial and economic processes associated with them.

Within this chapter we argue instead that the Sochi Olympics and the World Cup should be seen not simply as sporting events or even as inter- nationally-oriented projects staged to showcase 'great Russia', but rather as space-restructuring machines, of a particular extraverted character (Golubchikov, 2016, 2017; Golubchikov \& Slepukhina, 2014). In this regard, the aim of these events is to assist the federal government's attempts to modernise and restructure Russia's geography, based on promoting select locations as 'strategic growth poles' both economically and geopolitically, and forging them into the nodes of Russia's spatial modernisation. Mega events are thus leveraged to achieve spatial modernisation, including both through their short-term, spectacular function, but moreover through the longer-term infrastructural development intended to sustain the outwardly looking competitiveness and attractiveness, promoting subsequent tourism and investment. This top-down project of extraverted urbanism, while creating a new sense of centrality and regeneration for many cities, creates its own problems. However, its varied logics and consequences require due attention to counterbalance the prevalence of the aforementioned narratives.

The empirical material presented in this chapter rely on both secondary data - such as analytical materials and media reports related to both events, and primary data - derived from formal and informal interviews, at various levels of formality - which were collected as part of a larger research project. Expert interviews were carried out with academic researchers, FIFA officials, sports business and marketing personnel, government representatives at federal, regional and municipal levels, and representatives of civil society. We also included World Cup and Sochi Olympic volunteers and volunteer coordinators, journalists, business owners, urban professionals, market sellers and representatives of the general public in host cities. This equates to a combined total of over 200 interviews conducted over several years, with select extracts included here.

\section{Sports mega events and modernisation}

We argue that the mega events discussed here have been instrumental for the re-engagement of the Russian federal state with spatial governance following its retreat after the collapse of the Soviet Union. National-level statutory spatial planning was abandoned with the Soviet system of economic and spatial planning, but not meaningfully replaced with alternative national- level urban or spatial policies (Golubchikov, 2004). At the same time, cities and regions have limited fiscal autonomy to pursue realistic independent strategies, particularly in light of the fiscal centralisation under Putin, but also due to processes of economic polarisation resulting in a concentration of national wealth in cities like Moscow and some regional capitals (Golubchikov et al., 2015). Over the last decade the demand for national spatial policy has grown considerably.

Some scholars have found that by 2006, fractions in the Russian government became preoccupied with the idea of 'polarised' development, where a central role would be given to so-called 'growth poles' or 'growth engines', understood as territories already proven to be economically successful (Kinossian, 2013; Golubchikov et al., 2014). In practice, the logic of the 'territories of accelerated growth' was operationalised by ad hoc support for certain territories, in a mode of what can be called 'extraverted urbanism' (Golubchikov, 2017: 238). It has become standard practice for governments to invest large sums of public money in specifc localised 'hotspot' projects. A de-facto national urban policy has been oriented around event-based regeneration, such as in the context of hosting major sporting and cultural events and political summits, not only in Russia, but also in other ex-Soviet states (Golubchikov \& Badyina, 2016; Koch \& Valiyev, 2015). Apart from Sochi 2014 and the 2018 World Cup, notable examples of event-based regeneration in Russia included the APEC summit in Vladivostok in 2012 and the 2013 Summer Universiade in Kazan. 
In a 2011 speech in Davos, Dmitry Medvedev, then the President of Russia, included sports mega event projects in his list of top ten priorities in his agenda to modernise Russia:

[W]e have begun carrying out big infrastructure projects, especially as we have been chosen to host major international sports events. This is not just our sports fans' desire, but is a real opportunity to modernise our infrastructure, and it was precisely our goal to make our infrastructure more convenient for our people, for business and for trade. These projects will all be carried out on a public-private partnership basis. They will help us to develop individual regions. (Medvedev, 2011: no page)

This reflected situations in other comparable contexts around the world, where mega events have become increasingly associated with large-scale regional redevelopment and infrastructure projects, in which sport plays a legitimising role (Chalkley \& Essex, 1999; Coaffee, 2010). Sochi 2014 and the World Cup 2018 should therefore be seen in light of the wider political project of Russian modernisation, including the reemergence of spatial policy. This project seeks to rebalance territorial development away from the monocentricity of Moscow and to recalibrate the traditional sectoral approach of the federal government's economic development policy toward territorial development and urban policy. In the absence of nationallevel regional policy and spatial planning in Russia after the collapse of the planned economy, mega events and mega projects have become a 'hook' for the government to reterritorialise its development institutions and regain control (even if partially and unsystematically) over spatial and urban policy.

\section{The 2014 Sochi project: concentrated regeneration}

For midday on an October Monday, it may strike an international visitor as unusual to find sizeable pockets of people strolling along the remote Black Sea embankment next to the Sochi Olympic Park. Even outside the summer and winter seasons, families are enjoying themselves, local cafes are busy and some even venture swimming. Several years before, prior to the construction of the Olympic Park, this was a remote, marshy and rural place. Now the area features new stadiums, hotel complexes, modern residential blocks and a lavish railway station - set against the backdrop of the snow-covered peaks of the Caucuses Mountains. A young guide on a tourist cycle-car speaks of the new centrality given to this location: 'You feel like you are in the centre of everything happening here'. Being a fan of various sea-based activities, from yachting to diving and kitesurfing, he is excited about his move here from his hometown in Central Russia. He hopes to buy a \#at nearby and to properly settle in the area, and yet he also recognises the challenges he might incur:

Although the area has been transformed, it's still a resort, which has seasonality: a high and low season. It's not something good or bad, it's just what it is. But it creates conditions to which you need to adjust yourself if you live and work here. (October 2018, Sochi)

Since the end of the nineteenth century, Sochi has been considered one of Russia's prime sea resorts. Most of its territory was traditionally occupied by vacation centres and various sanatoriums - resort complexes that combine recreation and medical facilities. The economic troubles associated with the collapse of the Soviet Union and the opening of new opportunities for seaside tourism for Russians in places like the Mediterranean contributed to the post- Soviet dilapidation of many facilities in Sochi and the region as a whole. Sochi suffered from an unstable electricity and water supply and had the feel of a tired resort whose heyday had long since passed. However, everything has changed following the Winter Olympics of 2014.

As a result of its successful bid for the Winter Olympics, Sochi became the first Olympic city for which the entire main sports infrastructure was con- structed from scratch. Sochi clearly stands out for the scale of investment associated with the preparation for the 2014 Olympiad, commonly reported as US $\$ 50$ billion, which translates into well over US $\$ 150,000$ per head of the city's pre-Olympic population. This figure has already featured on numerous headlines, with many questioning the rationale and prudence of spending so much money on a single event. However, 80 per cent of that budget was actually directed at regional transformation rather than sporting infrastructure. The Olympics therefore provided the Russian state with leverage for a complete infrastructural overhaul of Sochi and the wider Krasnodar Kray region. 
The official framework programme for hosting the Olympics was the 'Federal Target Programme (FTP) for the Development of Sochi as a Mountain-Climate Resort' (RF Government, 2006). Its primary objective was to transform Sochi into Russia's first world-class alpine and year-round resort. The programme included the following targets: developing Sochi's physical infrastructure; modernising its urban environment; promoting Sochi as a tourist destination, making it competitive against leading international alpine re sorts; and increasing living standards and the gross regional product of Krasnodar Kray.

Consequently, the majority of costs were associated with a broad upgrade of urban and regional infrastructure, including power stations and supply, new water and sewerage systems, telecommunications and transport networks. Olimpstroy (the state corporation that oversaw the Sochi development) reported in its final budget statement published in June 2014 that the total allocated funds for the programme were RUB 1,524.4 billion (US\$49.5 billion) (Olimpstroy, 2014; Golubchikov, 2017). According to the Accounts (Audit) Chamber of the Russian Federation, the direct cost of hosting the Games and sporting facilities was RUB 324.9 billion (US $\$ 10.6$ billion), of which RUB 103.3 billion (US $\$ 3.4$ billion) was funded by the federal budget (ACRF, 2015). This suggests that 21 per cent of the total Sochi spending can be attributed specifically to the Winter Olympics, with the rest dedicated to more general urban and regional development. This is in line with Golubchikov's (2017) detailed analysis of different cost categories of the Olimpstroy's funds, confirming the focus on urban regeneration and infrastructural development (see Figure 13.1).

The logic of using the Winter Olympics as a leverage for regeneration, helping to build a new identity for Sochi, has been frequently repeated by official personnel. For instance, the then President of the Russian Olympic Committee Alexander Zhukov stated:

The effect of hosing the Olympic Games in Sochi can last for decades, because the quality of the resort city as such is changing. And the sport effect after the creation of the infrastructure will stay forever... Everyone knows that Sochi has been the main summer resort of the Soviet Union and Russia. In winter, its capacities were vacant. The idea has been to make Sochi an all-year-round resort, and the Olympic Games were a good pretext for that... I am sure it would have required many decades to make, without the Olympic Games in Sochi, such a colossal project. (ROC, 2013)

The composition of this extensive project was facilitated by rendering the Sochi project the top-down priority space within Russian federal politics. Müller (2011) has discussed the relevance of state-corporate relationships in the preparation for the Sochi project and identified a peculiar pattern of correlations, where the involvement of big business in the project was more about demonstrating loyalty to the state rather than achieving profits. Large corporations were the main sponsors of the Olympics and most of these are state-controlled, such as Gazprom and Rosneft. At the same time, key private investors took stateunderwritten credits from state-owned banks including VEB and Sberbank. In an analysis of corporate reports and federal budgets, the Anti-Corruption Foundation (FBK, 2014) has estimated the following breakdown of the approximately RUB 1.5 trillion costs attributed to Sochi: direct public budget costs - RUB 855 billion; expenses of state-controlled corporations - RUB 343 billion; VEB's loans to companies - RUB 249 billion; and equity of private companies - RUB 53 billion. It is likely that a large portion of VEB's loans have or will be written o\$ or restructured.

Sochi's Olympic infrastructure was developed in two clusters - mountain and coastal. The cluster approach has produced a concentration of all Olympic activities in the two areas, thus facilitating access and security measures. This also raised the issue of remoteness. The coaster cluster is located far from the urban core of Sochi and even from its actual host - the town of Adler - and is positioned on Russia's border with Abkhazia, the breakaway region of Georgia (discussed in Joel Rookwood's chapter in this volume). The political precarity and military instability of the disputed region across the border is also illuminated by Rook- wood (2019) in his analysis of sports events in Abkhazia, which serve as a counterpoint to Russia's recent portfolio in terms of resources, scale and impact.

As a consequence of the remoteness of some locations, various commentators predicted that such facilities were doomed to fall into disuse as 'white elephants' - a common criticism levelled at former mega event host cities around the world (Kissoudi, 2013). However, what is often overlooked is that the centralisation of power in Russia also influences the immediacies of administrative levers. Sochi's Olympic Park was not abandoned after the Games, but has instead been used to host numerous post-Olympiad sporting, cultural 
and business events. It has also become a key destination for tourists visiting Sochi, and a popular public park for local residents. Visitors can enjoy a host of museums, explore the Sochi amusement park or engage in various leisure activities in the Olympic Park itself or on the adjacent Black Sea embankments and other new recreational areas.

The city of Sochi itself has been retrofitted, and the continuous media and government attention, government-sponsored conferences and meetings and other events held there have helped rebrand the city. Hosting the Olympics has impacted geographical perspectives of the state in the eyes of the Russian population and beyond. The city administration estimated 6 million tourists would visit Sochi in 2015 (RSN, 2016), an increase on the 5.2 million arrivals in the Olympic year of 2014 (Vorobyev, 2015). This compares with 3.7 million visitors in 2006, before the Olympic project commenced. The new figures exceed the 5 million tourists Sochi received in its Soviet heyday. The passenger turnover at Sochi's airport grew from 1.2 million in 2005 to over 6.3 million in 2018 (see Table 13.1). Tourists are attracted to Sochi for various reasons, including the new or modernised skiing resorts, the Olympic parks, the sea resort facilities and the post-Olympic sporting events (IOC, 2015). The city also benefits from business events and conferences encouraged and facilitated by the government. The federal government's decision in 2017 to permit the construction of a gambling zone in Krasnaya Polyana (in the mountain cluster) further emphasises the uniqueness of the destination, as such facilities are normally forbidden (other gambling zones in Russia are remote and generally unsuccessful). Sochi has become a magnet for tourism, sporting events, conferences and other commercial and non-commercial activities, forming a certain 'growth pole' of (inter)national significance.

However, the top-down nature of the Sochi project, imposed on the city from outside, has not been without controversies, including questions regarding the extent to which local residents have actually benefited from or been excluded from the opportunities presented by the project. Local residents endured years of disruptive construction, often triggering temporary losses in tourism-related income. Hundreds were displaced from their homes, with several sites subject to compulsory purchase, and compensation only afforded to legally registered properties. Transport services were generally geared more towards tourists than residents, and infrastructural improvements like extending gas and water services have been spatially selective. Our interviews revealed that mushrooming property developments in Sochi are not considered attractive to local residents due to price or location, but target speculative buyers or wealthy newcomers who add to the growing congestion. Burgeoning populations in some areas have seen capacities exceeded relative to environmental and infrastructural limitations. In some cases, this has led to polluted water and malfunctions in the municipal waste system. In October 2018, two of Sochi Deputy Mayors and the head of Sochi Water Resources were arrested under allegations of corruption in the distribution of building and water permits. This coincided with a week of flooding in Greater Sochi, causing disruptions to various railway networks.

Such eventualities are perhaps not uncommon in the aftermath of mega events. Furthermore, as a coastal region Sochi is not immune from global climate fluctuations which can have local consequences. Severe flooding has impacted the new Olympic infrastructure such as highways and the airport, demonstrating the area's environmental sensitivity (BBC, 2018). However, Sochi's natural environment endured profound damage during Olympic preparations and many rushed event preparation projects were thought to have lacked sufficient engineering investigations and environmental audits (Gazaryan \& Shevchenko, 2014). In the eyes of some critical informants, the regeneration project should have taken a more environmentally and socially sensitive approach, which might have taken longer but could potentially have created more genuine benefits for the city-region, reducing some of the post- event challenges experienced. However, perhaps an alternative, pragmatic view is that without the time sensitive pressure of the Olympics, there would have been limited impetus for any strategic or extensive development of the region.

\section{The 2018 FIFA World Cup: distributed regeneration}

In a courtyard of of Prospekt Lenina in Volgograd, one of the eleven World Cup host cities, there is a small basement store that sells football paraphernalia and souvenirs. A year prior to four 2018 World Cup matches being held in the city, the owner of this store - a lifelong football fan - shared his thoughts: 'I hope that the championship will help business, of course. We want football to exist in Russia, but it's not really here... One reason is that there is no place for Rotor [the Volgograd football team] to practice, but that will change with the new stadium'. But when asked about the wider developments in preparation for hosting, 
he was more cynical: 'They are spending a whole pile of money. It is upsetting, of course. I only see a new airport, a new stadium, and roads - many new roads. This is all for tourists, not for us. But we are used to this" (April 2017, Volgograd).

For Russia, bidding for the rights to host both the Olympics and the World Cup indicated how seriously the state regards mega events, not only as a means of influencing domestic and international perceptions of the nation, but also in terms of its wide-ranging urban and regional development plans. The success of the bids and visitor figures also demonstrate global perceptions of Russian capacity in this regard. In the candidacy file submitted to FIFA, the Russian World Cup Bid Committee listed four overarching goals for hosting the World Cup: to open new markets for FIFA and world football, to increase investment in and accelerate the urban development of the host cities, to introduce Russian hospitality to the world, and to boost the level of Russian football nationwide (Russian World Cup Bid Committee, 2010).

The physical development of the host cities arguably served as the most fundamental aspect, for without the appropriate facilities and associated infrastructure the tournament could not have taken place. The driving force behind these material improvements was FIFA's hosting requirements, the guidelines that shape investments in host cities. FIFA's primarily expressed concerns are football stadia, training facilities, transit hubs such as airports and train stations, hotels - first for VIPs and athletes, and then more generally for the fans - and the roads and transport links that connect these sites. In addition to these mandated areas, Russian authorities embarked on ambitious infrastructure construction and modernisation plans that, according to the bid book, tied into each host city's individual development strategy. Andrey Bocharov, the Governor of the Volgograd region, offered the following viewpoint:

The World Cup will bring so much. A lot of work is going on right now and all these facilities will stay here to serve the people... Moreover, there is also massive, comprehensive work on public utilities, on the kind of facilities that aren't visible at first glance but that will provide an absolutely different quality of life... The most important thing is that all this will remain as a foundation for further development. All the facilities that are currently being built, developed, or reconstructed will remain as a legacy for the Volgograd region, for the hero city Volgograd, for the residents and for our guests.

(quoted in RIATs, 2017: no page)

The official framework for these developments is Government Decree No518 from 2013, the 'Preparatory Program for the 2018 Football World Cup in the Russian Federation', comprised of 272 individual projects distributed across the 11 host cities (RF Government, 2013). These include high-profile projects like expanding and improving central avenues, and less-visible improvements like building new power generators and upgrading sewage systems. This modernisation and investment in material infrastructure is perhaps more important in Russia's periphery than in major cities like Moscow and St Petersburg, where standards of living are relatively high, or in host cities like Sochi and Kazan, where previous mega events had already led to upgrades of the built environment. Fresh from its Olympics, Sochi required comparatively little investment to prepare for the World Cup: the airport, train station, hotel facilities and road infrastructure were already of a suitable standard for the hosting of prestigious international events. Most of the work required in Sochi involved retrofitting Fisht Stadium, which had hosted the Olympic opening and closing ceremonies, to make it suitable for international football. The seven other host cities (Yekaterinburg, Nizhny Novgorod, Samara, Rostov, Volgograd, Kaliningrad, and Saransk) had very limited collective experience in relation to event hosting, and many required substantial investment to improve their infrastructural capacity in line with FIFA standards.

Even among the 'millioniki' - cities with a population over a million - the level of pre-existing infrastructure fell below FIFA requirements, and time proved pressing (FIFA, 2016). Less than two years before the World Cup, Volgograd was still using its Soviet-era airport with only two waiting rooms and a total of 73 seats for departing passengers. Volgograd's new airport terminal which greeted guests for the World Cup is modern, spacious and befitting of a major regional city, fulfilling FIFA's requirements for peak traffic passenger figures in the process (see Table 13.1). Despite the many problems associated with event-based regeneration, Volgograd's airport had languished without necessary attention for many years, until the city was chosen to host the World Cup. A similar pattern can be found in many Russian host cities, where authorities attempted to harness the developmental impulse of mega event hosting in order to conduct necessary and long-overdue upgrades. 
Similar to the developments surrounding Sochi 2014, the majority of the World Cup budget was directed towards physical infrastructure and associated projects. The final budget totalled RUB 678.06 billion (US $\$ 13.3$ billion), with only 32 per cent earmarked for sports infrastructure like stadiums and training facilities (RF Government, 2017). The remainder was invested in construction and upgrades in infrastructure including transport, tele- communications, power and security. Furthermore, while 58 per cent of this budget came from the federal level, regional and private sources also contributed significantly and, in some cases, exclusively to certain project areas. Investments in health infrastructure came entirely from regional budgets and the construction of hotels and other accommodation was funded solely by private investors, although as with Sochi there have been instances of credits being issued from stateowned banks. One might assume therefore that the share of federal funds in the World Cup budget will actually have been higher than that officially claimed. Nevertheless, a key point here is that the majority of the World Cup budget was dedicated not for sport but for urban and regional development.

There were several problems with the implementation of this strategy however. Due to falling oil prices and economic sanctions, Russia entered a period of economic stagnation leading up to the World Cup. This stands in contrast to the preparations for the 2014 Sochi Olympics, which were con- ducted during a period of relative economic strength (even if preceded by the 2008 global financial crisis). Whilst the original budget for 2014 spiralled, the equivalent for 2018 was cut significantly. Between 2013 and 2016, Decree 518 was revised 23 times, introducing over 150 programme amendments and diminishing the budget by 44.4 billion rubles (US\$740 million). This altered the ways in which World Cup projects were managed and impacted the net- work of patron-client relationships that pervade much of Russia's business environment (Wolfe and Müller, 2018). As a consequence, the total number of infrastructure projects was significantly reduced. Even before these cuts how- ever, authorities in Moscow had already pledged to trim the World Cup development plans, with only the more significant items remaining. In 2013, Deputy Prime Minister Igor Shuvalov announced the reduction of the World Cup budget from 1.39 trillion rubles to 660 billion rubles: 'We've cut absolutely everything. There is nothing extraneous, not a single unnecessary facility [We have kept] only that which is connected to the World Cup' (Kazmin \& Rozhkov, 2013: no page).

This reduction in spending appears logical in light of market conditions, especially given the criticism over the high costs of Sochi 2014. The potential infrastructural legacy for the host cities was also drastically reduced however, with funding primarily invested in projects that served the short-term needs of the World Cup. One cancelled project was a long-awaited expansion of the single-line metro in Yekaterinburg. A station was planned next to the stadium site and would have served visitors to the World Cup, whilst breaking ground on the anticipated second line. However, municipal authorities were unable to secure funding from Moscow to undertake construction. The director of an urban development non-profit organisation in Yekaterinburg responded: 'It's a shame. If they cannot manage to open the second line for the World Cup, will we ever see it happen?' (November 2016, Yekaterinburg).

A similar consequence unfolded on a national scale, where a high-speed rail network was planned to link several host cities. This was part of the initial World Cup preparation plan designed to assuage FIFA's concerns that the vast distances between host cities would cause an over-reliance on air trans- port, threatening the operation of the tournament (FIFA, 2010). This new rail network would have linked Yekaterinburg to Moscow through Kazan and Nizhny Novgorod, with a second line connecting Sochi to Moscow via Rostov. This high-speed network would have cut travel times significantly and opened up longlasting improved connections to the capital. When it became clear in 2016 that the network would not be built, Alexey Polyansky (then the chief architect of the Rostov region, which would have benefited tremendously) expressed his disappointment:

We had hoped to complete the project quickly, but according to the latest information, we won't revisit this question until at least $2020 \ldots$... All we can do is to wait patiently. We'll have to be patient because the federal priority is the high-speed link between Moscow and Kazan. And that one is delayed too. (Abramova, 2016)

Even without the new train system however, the Russian transit system per-formed well during the World Cup. The country also provided visa-free access for ticket-holding foreigners and even offered free transport between and within host cities. Russia demonstrated a clear capacity to host international events, not only in major cities but in the periphery as well. However, questions remain concerning the overall legacy of these events, particularly since many projects proposed to be beneficial to residents were 
cancelled. This is especially salient for residents in peripheral host cities, who lack infra- structural advantages and employment opportunities in comparison with Russia's metropolises. While many of the infrastructure projects executed in the context of the World Cup have added value to their localities, problems remain with the selective nature of the developments and the ways in which projects of longlasting value were delayed or cancelled in favour of short- term priorities.

Furthermore, in the wake of the World Cup, questions have arisen concerning the quality of construction in some cases. Volgograd's stadium flooded following heavy rain, damaging the foundations and forcing the closure of the newly built adjacent embankment (Serebryakov, 2018). In Samara, complaints about the stadium construction quickly emerged after the event, as locals discovered cracks in the concrete foundations and holes in the stadium floor (Markov, 2018). Each host city has areas still in need of redevelopment, a common consequence when federal expenditure priorities are directed towards a major event at the expense of other localities.

However, when these investments \# ow largely to the central areas of the city where tourists are more likely to frequent, is it any wonder that many locals feel neglected and excluded? Kaliningrad's mayor actually encouraged residents to leave town for the duration of the World Cup so as not to interfere with the event hosting (Interfax, 2017). Aside from these exclusions, there is also a longer-term developmental strategy to consider here, where regional authorities attempt to increase tourism, mainly (but not exclusively) for domestic audiences. While not many cities enjoy the natural advantages of a resort like Sochi, it is also true that airport arrivals have increased dramatically for many host cities in the run up to the World Cup (see Table 13.1). It remains to be seen whether these cities can follow in Sochi's footsteps and maintain a positive tourism performance.

\section{Conclusion}

This chapter has examined the role of the state and the politics of space, adopting a comparative analysis of the 2014 Winter Olympics and 2018 World Cup. While related literature often considers Russian state politics in relation to those events through the lens of President Putin's nationalism and/ or authoritarianism, these perspectives inhibit the understanding of existing complexities and the dynamics of these events. We have argued that the two tournaments have been critical for Russia's spatial restructuring. While Sochi was naturally more place-centric, the World Cup was distributed across 11 di\$erent cities. However, what has emerged in the host cities is mixed and spatially variegated: some significant and welcome material investments were made, but some areas were subject to contested developments and poor planning. Overall, both events represent shifts in Russia's regional policies and a selective return of the federal state to the sphere of urban development. They also highlight the contradictions of the 'extraverted' politics of space.

In relation to the analysis of state-led urban development, some scholars have argued for 'the need to further conceptualise nation-state politics and autocratic rule as driving forces of urban development processes' (Grubbauer and Camprag, 2018: 3). This chapter has highlighted the role of the Russian federal state in leveraging the opportunities offered by hosting editions of two of the world's major sporting events, in crafting selective extraverted mod- alities of spatial governance (Golubchikov, 2010, 2017). This extraverted urbanism emerges from the interplay between Russia's internal needs for spatial modernisation on the one hand, and the external geopolitics of state- led mega projects on the other (Büdenbender \& Golubchikov, 2017). How- ever, beneath this general level of conceptualisation, there are also notable di\$erences between the two mega-events.

Preparations for Sochi involved steep learning curves for the federal government - not only concerning the importance of comprehensive regional regeneration, but also regarding possibilities and limitations in shaping places directly, bypassing or overcoming administrative hierarchy (at federal, regional and municipal levels) in dealing with local territories that have been deemed nationally significant. This did not always prove a straightforward policy process, given the significant work involved in preparing for events of this magnitude, especially in Sochi. This was complicated not only by the absence of suitable pre-existing sports infrastructure, but also by the presence of prevailing challenges, hierarchies and practices in Russia. This includes negotiating vested interests and conflicts and engaging with various inter- personal and interorganisational networks, comprised of international, national and local actors, public and private, business and civic. Such demands occurred whilst also having to provide necessary regulatory and procedural 
frameworks and leveraging huge budgetary, extra-budgetary and non-budgetary/corporate funds, performing the power of order, persuasion or pressure in order to get things done as promised, designed, planned and needed. In other words, Sochi has been a site of experimentation for the Russian government, emerging outside of the more traditional spatiality of hierarchy and regulation.

World Cup developments followed some of the same patterns as the Winter Olympics, and there are enough similarities in the trajectory of these projects to surmise that the authorities attempted to apply the lessons of Sochi to a new set of localities. At the same time, developments for this World Cup were obviously dispersed rather than concentrated in one city. There were also differences in the type of sports facilities required. The Winter Olympics helped transform the Sochi region, creating a new ski resort city in the Caucasus Mountains. By comparison the World Cup is a much less diverse mega event in terms of sporting infrastructure. With respect to other infrastructural developments in World Cup host cities, planning authorities prioritised developments around FIFA's requirements, centred on the areas critical for the World Cup. Aside from the stadiums and training venues, this included transit hubs, hotels and roads connecting them, as well as less visible infra- structure such as power and sewage. Many of these initial developments could have provided a substantial benefit to the cities and regions, servicing long- term needs rather than merely satisfying the requirements of a short-term sporting event. However, the contractual obligations of inflexible mega event deadlines force attention on certain projects, often at the expense of others. This is one reason why a World Cup stadium will always be completed, while other less visible or less protected projects endure delays, or even cancellations. The economically troubled conditions in Russia connected to its conflict with the West since 2014 only served to exacerbate this situation, resulting in a reduced scope of infrastructure developments for host cities. There have also been significant inequalities perpetuated throughout the mega event preparation cycle, with a common theme of spatially selective developments aimed more at tourists than residents.

However, in both the Olympics and the World Cup, regardless of perceived successes or failures of infrastructural development programmes, it is clear that there is more happening in Russian mega event development than is typically portrayed by the western press or even in the academy. Rather than analysing these events merely from the perspective of 'Putin's Russia', where the Russian president is central to any explanatory factor for every event, the urban development produced through the Olympics and World Cup provide an opportunity to understand a shift in the relations between the federal state and Russia's regions. This allows for a more nuanced understanding of the politics and production of space in contemporary Russia, as event-led development drives modernisation in the peripheries, shifting from Moscow-centricity a more polycentric model, however uneven and imperfectly executed this may be.

\section{Funding}

This work was supported by a Swiss National Science Professorship directed by Prof. Martin Müller under grant numbers PP00P1_144699 and PP00P1_172891.

\section{References}

Abramova, M. (2016) Vvod zheleznodorozhnoi magistrali Moskva - Rostov - Sochi otkladivaetsya [Moscow - Rostov Sochi train line delayed]. 161.ru, 16 March.

ACRF (2015) Analiz mer po ustraneniyu narusheniy pri podgotovke i provedenii XXII Olimpiyskikh zimnikh igr i XI Paralimpiyskikh zimnikh igr 2014 goda v Sochi [The analysis of measures on the elimination of irregularities in the preparation and hosting of XXII Winter Olympic Games and XI Winter Paralympic Games of 2014 in Sochi]. Moscow: The Accounts Chamber of the Russian Federation (ACRF). Available from:

http://audit.gov.ru/press_center/news/21280 [Accessed June 2016].

Anderson, B. (2006) Imagined Communities: Refiections on the Origin and Spread of Nationalism. London, Verso.

Arnold, R. \&Foxall, A. (2014) Lord of the (five) rings. Problems of Post-Communism, 61(1), 3-12.

BBC (2018) Potop v Sochi: Putin obeshaet pomosh, mashini i poezda snova mogut proekhat [Flooding in Sochi: Putin promises help, cars and trains can once again travel]. 27 October. 
Black, D. \&Westhuizen, J. V. D. (2004) The allure of global games for 'semi-peripheral' polities and spaces: A research agenda. Third World Quarterly, 25(7), 1195-1214.

Büdenbender, M. \&Golubchikov, O. (2017) The geopolitics of real estate: Assem- bling soft power via property markets. International Journal of Housing Policy, 17 (1), 75-96.

Chalkley, B. \&Essex, S. (1999) Urban development through hosting international events: A history of the Olympic Games. Planning Perspectives, 14(4), 369-394.

Coa\$ee, J. (2010) Urban regeneration and renewal. In: J. R. Gold \& M. M. Gold (eds) Olympic Cities: City Agendas, Planning, and the World's Games. London, Routledge, pp. 180-193.

Cornelissen, S. (2010) The geopolitics of global aspiration: Sport mega-events and emerging. The International Journal of the History of Sport, 27(16-18), 3008-3025.

FBK (2014) Sochi 2014: Encyclopedia of Spending. Moscow: FBK (Anti-Corruption Foundation). Available from: http://sochi.fbk.info/en [Accessed June 2016].

FIFA (2010) 2018 FIFA World Cup Bid Evaluation Report. Russia.

FIFA (2016) FIFA World Cup: Event Transport Handbook. Zurich.

Gazaryan, S. \&Shevchenko, D. (2014) Sochi-2014: Independent Environmental Report: Environmental Watch on North Caucasus. Russia.

Golubchikov, O. (2004) Urban planning in Russia: Towards the market. European Planning Studies, 12(2), $229-247$.

Golubchikov, O. (2010) World-city-entrepreneurialism: Globalist imaginaries, neo-liberal geographies, and the production of new St Petersburg. Environment and Planning, 42(3), 626-643.

Golubchikov, O. (2016) The 2014 Sochi Winter Olympics: Who stands to gain? In: Transparency International (ed.) Global Corruption Report: Sport. Abingdon, Routledge, pp. 183-191.Golubchikov, O. (2017) From a sports megaevent to a regional mega-project: The Sochi winter Olympics and the return of geography in state development priorities. International Journal of Sport Policy and Politics, 9(2), 237-255.

Golubchikov, O. \&Badyina, A. (2016) Makroregionalnye tendentsii razvitiya gorodov byvshego SSSR [The macroregional trends in the development of cities in the ex-USSR states]. Regionalnye Issledovaniya, 52(2), 31-43.

Golubchikov, O. \&Slepukhina, I. (2014) Russia: Showcasing a 're-emerging' state? In: J. Grix (ed.) Leveraging Legacies from Sports Mega-Events. London, Palgrave Macmillan, pp. 166-177.

Golubchikov, O., Badyina, A. \&Makhrova, A. (2014) The hybrid spatialities of transition: Capitalism, legacy and uneven urban economic restructuring. Urban Studies, 51(4), 617-633.

Golubchikov, O., Makhrova, A., Badyina, A. \&Brade, I. (2015) Uneven urban resilience: The economic adjustment and polarization of Russia's cities. In: T. Lang, S. Henn, W. Sgibnev\& K. Ehrlich (eds) Understanding Geographies of Polarization and Peripheralization: Perspectives from Central and Eastern Europe and Beyond. Basingstoke, Palgrave Macmillan, pp. 270-284.

Grix, J. \&Brannagan, P. M. (2016) Of mechanisms and myths: Conceptualising states' 'soft power' strategies through sports mega-events. Diplomacy \& Statecraft, 27(2), 251-272.

Horne, J. \&Manzenreiter, W. (2006) An introduction to the sociology of sports mega- events. The Sociological Review, $54,1-24$. 
Grubbauer, M. \&Camprag, N. (2018) Urban megaprojects, nation-state politics and regulatory capitalism in Central and Eastern Europe: The Belgrade Waterfront project. Urban Studies, 56(4), 649-671.

Interfax (2017) Mer Kaliningrada posovetoval zhitelyam uyekhat iz goroda na vremya ChM2018 [Kaliningrad mayor recommends residents leave city during WC2018]. 18 October.

IOC (2015) Factsheet: Sochi 2014 Facts and Figures, update - February 2015. Lau- sanne, International Olympic Committee (IOC). Available from: https://stillmed.

olympic.org/Documents/Games_Sochi_2014/Sochi_2014_Facts_and_Figures.pdf [Accessed 1 June 2016].

Kazmin, D. \&Rozhkov, A. (2013) Smetu ChM2018 udalos snizit vdvoe [World Cup 2018 budget cut in half]. 24 May.

Kinossian, N. (2013) Stuck in transition: Russian regional planning policy between spatial polarization and equalization. Eurasian Geography and Economics, 54(5-6), 611-629.

Kissoudi, P. (2013) The Athens Olympics: Optimistic legacies - post-Olympic assets and the struggle for their realization. In: J. A. Mangan\& M. Dyreson (eds) Olympic Legacies: Intended and Unintended: Political, Cultural, Economic and Educational. New York, Routledge, pp. 89-107.

Koch, N. \&Valiyev, A. (2015) Urban boosterism in closed contexts: Spectacular urbanization and second-tier megaevents in three Caspian capitals. Eurasian Geo- graphy and Economics, 56(5), 575-598.

Markov, E. (2018) Samara - klass, a vot naslediye ChM - grust. Stadion uzhe grazny i v treshinakh [Samara is cool but the World Cup legacy is sadness. The stadium is already dirty and cracking]. Sprts.ru. 2 November.

Medvedev, D. (2011) Excerpts from opening address by Dmitry Medvedev to the World Economic Forum in Davos. Available from: http://en.kremlin.ru/misc/10663 [Accessed 1 June 2018].

Müller, M. (2011) State dirigisme in megaprojects: Governing the 2014 Winter Olym- pics in Sochi. Environment and Planning, 43(9), 2091-2108.

Müller, M. (2014) Introduction: Winter Olympics Sochi 2014: What is at stake? East European Politics, 30(2), 153157.

Müller, M. \&Pickles, J. (2015) Global games, local rules: Mega-events in the post- socialist world. European Urban and Regional Studies, 22(2), 121-127.

Nureev, R. M., Markin, E. V. \&Grechkin, M. A. (2014) XXII Olimpiiskie zimnie igri 2014g. v Sochi: pervie itogi [The 22nd Winter Olympic Games in Sochi 2014: Initial results]. Journal of Economic Regulation, 5(2), 14-32.

Olimpstroy (2014) Forma 14: Otchet ob osuschestvlenii stroitelstva olimpiyskikh obyektov i vypolnenii inykh meropriyatiy, svyazannykh so stroitelstvom olimpiys- kikh obyektov za 2013 god [Form 14: report on the implementation of Olympic construction and other related activities for the year 2013]. Sochi, Olympstroy.

Petersson, B., Vamling, K. \&Yatsyk, A. (2015) When the party is over: Developments in Sochi and Russia after the Olympics 2014. Sport in Society, 20(4), 455-460.

Preuss, H. \&Alfs, C. (2011) Signaling through the 2008 Beijing Olympics: Using mega sport events to change the perception and image of the host. European Sport Man- agement Quarterly, 11(1), 55-71.

RF Government (2006) Decree from 08.06.2006 N357 on the Federal Target Pro- gramme 'The Development of the City of Sochi as a Mountain Climate Resort (in 2006-2014)'. Government of the Russian Federation.

RF Government (2013) O Programme podgotovki k provedeniu v 2018 godu v Ros- siskoi Federatsii chempionata mira po futbolu [Preparatory program for the 2018 Football World Cup in the Russian Federation - 2013 edition]. 20 June.

RF Government (2017) O Programme podgotovki k provedeniu v 2018 godu v Ros- siskoi Federatsii chempionata mira po futbolu \#1277 [Preparatory program for the 2018 Football World Cup in the Russian Federation - 2017 edition, \#1277]. 16 December. 
RIATs (2017) Andrey Bocharov postavil zadachi po itogam inspektsii obyektov, vkhodyashikh v perechen ChM2018 [Andrey Bocharov assigns tasks for the inspection of WC2018 facilities]. July 26.

ROC (2013) Informatsionnyi sportivnyi Bulleten OKR za 30 sentyabrya 2013 golda [Information sport bulletin of ROC from 30.09.2013: Russian Olympic Committee (ROC)]. Available from: www.olympic.ru/news/digest/informaczionniy-sportivniy- byulleten-30-09-13 [Accessed 1 June 2016].

Rookwood, J. (2019) The politics of ConIFA: Organising and managing international football events for unrecognised countries. Managing Sport and Leisure, 24(5), 1-15.

RosAviatsia (2019) Obyomy perevozki cherez aeroporty Rossii [Passenger tra"c through Russian airports]. Available from: www.favt.ru/dejatelnost-ajeroporty-i-ajer odromy-osnovnie-proizvodstvennie-pokazateli-aeroportov-obyomperevoz/ [Accessed 1 June 2016]. RSN (2016) Mer Pokhomor: Sochi v 2015 godu posetili 6 millionov turistov [Mayor

Pakhomov: Sochi was visited by 6 million tourists in 2015]. 7 February. Available from: http://rusnovosti.ru/posts/407955 [Accessed 1 June 2016]. Russian World Cup Bid Committee (2010) Ready to Inspire: Russia 2018/2022 FIFA World Cup Bid Book. Moscow.

Serebryakov, A. (2018) Volgograd nakryl liven: molniya razrushaet stenu, rokadnaya doroga zakrya [Volgograd flooded: lightning destroys a wall, new river road is closed]. V1.ru. 22 July.

Vorobyev, A. (2015) Sochi stal vtorym po populyarnosti gornolyzhnym kurortom v Rossii [Sochi has become the second most popular mountain ski resort in Russia]. Vedomosti. 29 April. Available from: www.vedomosti.ru/business/articles/2015/04/29/sochi-stal-vtorim-po-populyarnosti-gornolizhnim-kurortom-vrossii [Accessed 1 June 2016].

Wolfe, S. D. (2015) A silver medal project: The partial success of Russia's soft power in Sochi 2014. Annals of Leisure Research, 19(4), 481-496.

Wolfe, S. D. \&Müller, M. (2018) Crisis Neopatrimonialism: Russia's new political economy and the 2018 World Cup. Problems of Post-Communism, 65(2), 101-114. 